$\begin{array}{lll}\text { DE DE GRUYTER } & \begin{array}{l}\text { MINERALOGIA, 47, No 1-4: 3-5 (2016) } \\ \text { DOI: 10.2478/mipo-2018-0005 } \\ \text { Www.Mineralogia.pl } \\ \text { MINERALOGICAL SOCIETY OF POLAND } \\ \text { POLSKIE TOWARZYSTWO MINERALOGICZNE }\end{array}\end{array}$

Printed in 2017

\title{
Prof. dr hab. Alexei Nikolaievich Platonov (1937-2016)
}

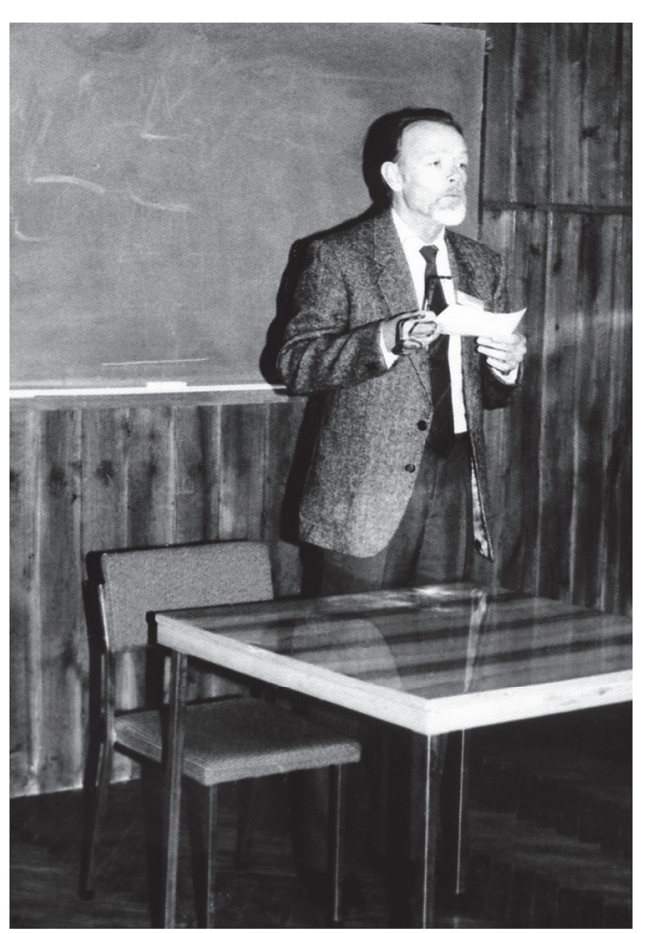

Professor A.N. Platonov at the International Schools of Physics of Minerals in Karpacz, Poland, 18-24.09.1988. (fot. Wanda Szymańska-Stachowiak).
Professor Alexei Nikolaevich Platonov, a prominent mineralogist, an Honorary Member of the Mineralogical Society of Poland, and an active Member of the Editorial Board of the journal Mineralogia, passed away on 22 March 2016. He was born on the $6^{\text {th. }}$ of September 1937 in Chita, southern Siberia, Russia, where his parents, Nikolai Nikolaievich Platonov and Viera Alexeevna Semyonova, worked in a district military hospital. As A.N. Platonov used to point out, his interests in minerals began with a visit to a local museum, where he became fascinated by a collection of mineral resources of the Transbaikal region. A splendid specimen of blue aquamarine was so much engraved in his memory, that it later became his "pole star", guiding him to the pinnacles of his scientific career. In 1949, the Platonov family moved to Kiev, where the young Alexei Nikolaevich studied books by Fersman (Reminiscences about Minerals and Mineralogy for Everyone), Yakovlev (In the Word of Stones) and Lazarenko (Course on Mineralogy), and developed a passion for mineralogy. After graduating with a gold medal from secondary school, he received his university education at the Geological Faculty of the Taras Shevchenko National University of Kiev, Ukraine. In 1959, he graduated with honors, defending the thesis devoted to the morphology, anatomy and origin of beryl crystals from pegmatites of 
the Kamennaya Mogila complex, Priazovie, Ukraine. Soon afterwards, he participated in the South-Ukrainian Geological Expedition and took part in the drawing of a 1:200,000 geological map of this region. In 1960, he joined the Second North-Kazakhstan Expedition and co-authored the 1:50 000 geological map of the area of Kokchetav, Kazakhstan. While documenting the sampling material collected during this expedition, he took an interest in accessory mineralization, especially in the crystal morphology of anatase and titanoniobates from granitic pegmatites of northern Kazakhstan. In 1961, A.N. Platonov was employed in the Mineralogical Department of the Institute of Geological Sciences of the Ukrainian Academy of Sciences and published his first scientific contributions. Under the supervision of the famous Ukrainian mineralogist, A.C. Povarennych, he worked there on the problem of color of minerals and on theoretical- and methodological aspects of optical absorption spectroscopy of minerals. From then, the origin of color in minerals became his major field of scientific interest. To deepen his knowledge on the physical nature of color, A.N. Platonov completed post-graduate studies at the Institute of Solid State Physics at the Academy of Sciences USSR in Moscow. In 1968, under the supervision of A.S. Marfunin, one of the founders of the physics of minerals, A.N. Platonov received the title of Candidate of Sciences $(\mathrm{PhD})$, having submitted a dissertation on physical properties, polytypism and isomorphism of sphalerites. A year later, he was employed in the newly formed Institute of Geochemistry and Physics of Minerals (since 1993 the Institute of Geochemistry, Mineralogy and Ore Formation), at the Academy of Science of Ukraine in Kiev. His later career from Senior Researcher to Professor is inseparably associated with this institute. Among other administrative duties, he was the Head of the Department of Crystalochemistry and Mineralogy from 1975-2003 and of the Department of Spectral Methods in Mineralogy and Vice-Head of the Institute for science from 1978-1981. In March 1974, at the age of 36, A.N. Platonov received the title of Doctor of Science in Geology and Mineralogy (PhD habilitated), defending the dissertation on Experimental and theoretical investigations on the nature and typomorphic meaning of color in minerals. The dissertation was highly evaluated as an important contribution to the development of mineralogy. Thus, A.N. Platonov joined the exclusive club of pioneers in the field of optics and spectroscopy of minerals and the physics of minerals in general. Soon, he was appointed to a Chair in the Committee of Physics of Minerals of the Mineralogical Association of the Academy of Science of the U.S.S.R.

A.N. Platonov published his first contributions on the color of minerals in the 1960s. The results of his long-time studies were presented in the books The Nature of the Color of Minerals (1976; with M.N. Taran and V.S. Balitsky) and The Nature of the Color of Gemstones (1984; with S.S. Matsuk and V.M. Khomenko), regarded among the best works on this topic ever published. An important aspect of the scientific career of A.N. Platonov was the investigation of rock-forming minerals by means of optical absorption spectroscopy. Together with his research associates and co-workers, he demonstrated that trichromatic colorimetry, optical spectroscopy and chromatic analysis can be successfully used for defining colors of minerals, and enabling conclusions on the crystallochemical features and genetic aspects of mineral species. The results of these investigations, published in numerous papers and books, led to the concept of active color centers as typomorphic features of minerals that allow the use of various colors of minerals as genetic- and crystallochemical indicators. This approach helped to answer many 
fundamental problems in mineralogy and is still employed as one of the methods in prospecting for ores, solving issues concerning ore formation, and evaluating colored gemstones.

A.N. Platonov was one of the world's leading experts in the physics of minerals, the author and co-author of over 300 scientific contributions and 9 monographic publications. For the book The Nature of the Color of Minerals, he was awarded the State Prize of the Ukrainian S.S.R. in the Field of Science and Technology in 1983. In 1993, for the entirety of his scientific achievements, he was granted the prestigious Humboldt Research Award by the Alexander von Humboldt Foundation. A.N. Platonov was a Member of the Ukrainian Mineralogical Society, the Russian Mineralogical Society and the German Mineralogical Society. In 1996, he also became an Honorary Member of the Mineralogical Society of Poland.

Apart from his scientific achievements, A.N. Platonov was very active as an academic teacher. For many years, he taught courses on new methods in mineralogical research and on prospective mineralogy at the Geological Faculty of the Taras Shevchenko National University in Kiev, Ukraine, as well as various courses at the National Gemological Centre of Ukraine. For many years, he shared his knowledge as a guest speaker at International Schools of Physic of Minerals, a series of workshops organized by the University of Wrocław in Poland. For 13 years, A.N. Platonov was a working editor, and then the viceeditor of the journal Constitution and Characteristics of Minerals, a member of the editorial board of Physics and Chemistry of Minerals, Proceedings of the Russian Mineralogical Society, Mineralogical Journal (Ukraine), and Mineralogia Polonica (presently Mineralogia).

Professor A.N. Platonov was a giant of mineralogy and a man of extremely broad knowledge. He was a mentor and tutor for many younger scientists, always remaining kind, friendly and warm-hearted, eager to share his experience with others. He was also a close friend of the Polish and a frequent visitor to Poland. He cooperated with many Polish mineralogists and petrologists, consulting and co-authoring numerous scientific contributions, giving lectures and inspiring joint research projects.

On the behalf of Professor Platonov's friends, co-workers and students: Michat Sachanbiński and Adam Szuszkiewicz 